\title{
Pengaruh Pemberian Probiotik terhadap Laju Pertumbuhan dan Kelulushidupan Belut (Monopterus albus) pada Sistem Bioflok
}

\author{
The Effect of Probiotics to Growth and Survival Rate of Swamp Eel \\ (Monopterus albus) in the Biofloc System \\ Ardian Putra Firdani ${ }^{1 *}$, Niken Ayu Pamukas ${ }^{1}$, Usman M. Tang ${ }^{1}$ \\ ${ }^{1}$ Jurusan Budidaya Perairan, Fakultas Perikanan dan Kelautan, Universitas Riau \\ email: ardianputrafirdani28@gmail.com
}

(Received: 18 Juni 2021; Accepted: 02 Juni 2021)

\begin{abstract}
ABSTRAK
Belut (Monopterus albus) adalah komoditas perikanan air tawar yang bernilai ekonomi cukup tinggi, permintaan pasar yang tinggi namun ketersediaannya di alam mulai sulit ditemukan maka perlu melakukan peningkatan produksinya. Salah satu upaya yang dapat dilakukan adalah intensifikasi budidaya belut dengan sistem bioflok. Tujuan dari penelitian ini adalah untuk menentukan dosis probiotik terbaik yang ditambahkan ke media pemeliharaan, dalam meningkatkan volume flok, pertumbuhan dan kelulushidupan belut. Penelitian ini dilaksanakan pada bulan Juni hingga Juli 2020, bertempat di UPT Kolam Percobaan Fakultas Perikanan dan Kelautan Universitas Riau. Hewan uji yang digunakan adalah belut yang berukuran $10-15 \mathrm{~cm}$ dengan lama pemeliharaan 40 hari. Penelitian ini menggunakan Rancangan Acak Lengkap (RAL) satu faktor yang terdiri dari lima taraf perlakuan dengan tiga kali ulangan sehingga diperlukan 15 unit percobaan Taraf perlakuan yang digunakan pada penelitian ini sebagai berikut: $\mathrm{P}_{0}$ (Tanpa diberi probiotik boster sel multi $0 \mathrm{ml} / \mathrm{L}$ air), $\mathrm{P}_{1}$ (Dosis probiotik boster sel multi $0,6 \mathrm{~mL} / \mathrm{L}$ air), $\mathrm{P}_{2}$ (0,9 mL/L air), $\mathrm{P}_{3}\left(1,2 \mathrm{~mL} / \mathrm{L}\right.$ air) dan $\mathrm{P}_{4}(1,5 \mathrm{~mL} / \mathrm{L}$ air $)$. Hasil penelitian menunjukkan bahwa pemberian probiotik pada media pemeliharaan belut memberikan pengaruh terhadap pertumbuhan dan kelulushidupan belut. Dosis $0,9 \mathrm{~mL} / \mathrm{L}$ memberikan hasil terbaik terhadap pertumbuhan bobot multak, laju pertumbuhan spesifik, panjang mutlak, tingkat kelulushidupan masing masing sebesar $18,91 \mathrm{~g}, 3,59 \%, 15,53 \mathrm{~cm}$, dan $75,55 \%$. Selanjutnya kualitas air selama penelitian masih dapat ditoleransi oleh belut, seperti suhu berkisar antara $26-30^{\circ} \mathrm{C}$, pH 5-7, DO 6,0-7,4 mg/L, dan $\mathrm{NH}_{3}$ 0,00001-0,0005 mg/L.
\end{abstract}

Kata Kunci: Bioflok, Belut, Dosis, Pertumbuhan

\begin{abstract}
Swamp eel (Monopterus albus) is a freshwater fishery commodity that has high economic value, high market demand but its not availability in a wild. It was to be difficult to find, so it is necessary to increase this production. Which one of the efforts to can be is intensification of eel cultured with the biofloc system. The aimed of this study was to find out the best probiotic dose to added to the maintenance media cultivation, in order to increase floc volume, growth and survival rate of the swamp eels. This research was conducted from June to July 2020. Located this research at the UPT research pond Faculty of Fisheries and Marine, Riau University. The eels used in this study were $10-15 \mathrm{~cm}$ in size with 40 days of maintenance. This study used a one-factor completely randomized design (CRD) consisting of five levels of treatment with three repetitions so that 15 experimental units were needed. P1 (Multi Cell Boster Probiotic dose $0.6 \mathrm{~mL} / \mathrm{L}$ water), P2 (0.9 $\mathrm{mL} / \mathrm{L}$ water), $\mathrm{P} 3(1.2 \mathrm{~mL} / \mathrm{L}$ water) and $\mathrm{P} 4(1.5 \mathrm{~mL} / \mathrm{L}$ water $)$. The results showed that the provision of probiotics in eel maintenance media had an effect on the growth and survival of the eels. The dose of $0.9 \mathrm{ml} / \mathrm{L}$ gave the best results on multi-weight growth, specific growth rate, absolute length, and survival rates of $18.91 \mathrm{~g}, 3.59 \%, 15.53 \mathrm{~cm}$, and $75.55 \%$, respectively. Furthermore, the
\end{abstract}


water quality during the study was still tolerable by eels, such as temperatures ranging from 2630oC, pH 5-7, DO 6.0-7.4 mg/L, and NH3 0.00001-0.0005 mg/L.

Keyword: Biofloc, Swamp eel, Doses, Growth

\section{Pendahuluan}

Belut (Monopterus albus) adalah komoditas perikanan air tawar yang bernilai ekonomi cukup tinggi. Belut merupakan sumber protein hewani yang dianjurkan untuk dikonsumsi oleh segala tingkatan usia. Belut dapat dikonsumsi langsung dalam berbagai bentuk masakan olahan yang bernilai tinggi. Menurut Astawan (2008) dalam $100 \mathrm{~g}$ daging belut mengandung energi $303 \mathrm{kkal}$, protein $18,4 \mathrm{~g}$, zat besi $20 \mathrm{mg}$, vitamin A $1.600 \mathrm{SI}$, vitamin D sepuluh kali dari daging, asam lemak omega 3, serta fosfor dua kali dari daging dan telur.

Belut juga merupakan salah satu jenis komoditas ekspor andalan Indonesia (Mashuri et al., 2012). Hal ini dikarenakan permintaan belut baik di pasar domestik maupun mancanegara cenderung meningkat, seperti permintaan negara-negara di kawasan Asia, mencapai 60 ton per hari dan hanya terpenuhi 10 persen dari angka tersebut (Muktiani, 2011).

Semakin meningkatnya permintaan pasar terhadap belut menyebabkan penangkapan belut dari alam semakin meningkat, sehingga dikhawatirkan dapat mengurangi populasinya. Budidaya belut menjadi solusi sekaligus peluang bisnis yang menguntungkan. Budidaya belut yang telah dilakukan masih menemuikendala yaitu pembuatan media budidaya yang tidak sesuai dengan habitat aslinya, karena banyak terjadi kegagalan dalam usahanya. Budidaya belut ini masih sangat terbatas (Saparinto, 2012). Budidaya belut dalam media air jernih memberikan hasil cukup baik dilihat dari hasil laju pertumbuhan spesifik 2,69\% dan sintasan 93,3\% (Perdana, 2013: Nurrahmad, 2020). Selain itu budidaya belut di dalam air jernih memberikan keuntungan karena mudah melakukan pengamatan, pengontrolan dan pemanenan belut. Salah satu budidaya intensif yang dapat diaplikasikan adalah budidaya belut dengan sistem bioflok.

Teknologi bioflok menjadi salah satu alternatif pemecah masalah limbah budidaya intensif. Teknologi bioflok mampu menyediakan pakan tambahan berprotein untuk hewan budidaya sehingga dapat meningkatkan pertumbuhan, selain itu teknologi ini juga efektif menurunkan limbah nitrogen anorganik dari sisa pakan dan kotoran (Avnimelech, 2009). Penerapan teknologi bioflok memiliki prinsip memanfaatkan limbah ammonia dan nitrit pada kolam budidaya menjadi bahan pakan alami dengan bantuan bakteri heterotrofik. Walaupun demikian, proses penyerapan nitrogen anorganik oleh bakteri hanya terjadi ketika rasio $\mathrm{C} / \mathrm{N}$ lebih tinggi dari sepuluh (Ma'in et al., 2013).

Penerapan teknologi bioflok dalam budidaya ikan dan udang telah berhasil dilakukan, hal tersebut memungkinkan untuk diterapkan pada budidaya belut sawah, sehingga menjadi solusi untuk meningkatkan kebutuhan pasar terhadap belut sawah dan juga dapat tercipta akuakultur yang berkelanjutan dan ramah lingkungan. Keberhasilan pembentukan flok sebagai pakan alami organisme budidaya dalam sistem bioflok sangat ditentukan oleh pemberian dosis bakteri (probiotik) yang tepat.

Berdasarkan uraian di atas penulis tertarik untuk melakukan penelitian mengenai pengaruh pemberian probiotik dengan dosis berbeda terhadap laju pertumbuhan belut yang dipelihara pada sistem bioflok.

\section{Metode Penelitian}

\subsection{Waktu dan Tempat}

Penelitian ini telah dilaksanakan pada bulan Juni hingga Juli 2020. Penelitian ini dilakukan di UPT Kolam Percobaan Fakultas Perikanan dan Kelautan Universitas Riau.

\subsection{Metode Penelitian}

Penelitian ini menggunakan Rancangan Acak Lengkap (RAL) satu faktor yang terdiri dari lima taraf perlakuan dengan tiga kali ulangan sehingga diperlukan 15 unit percobaan. Sedangkan taraf perlakuan ditetapkan berdasarkan penelitian terbaik dari Matondang et al. (2019) yang mendapatkan dosis probiotik terbaik $0,45 \mathrm{~mL} / \mathrm{L}$ pada pemeliharaan ikan Baung. Taraf perlakuan 
yang digunakan pada penelitian ini sebagai berikut:

$\mathrm{P} 0=$ Tanpa diberi probiotik boster sel multi $0 \mathrm{~mL} / \mathrm{L}$ air

$\mathrm{P} 1=$ Dosis $0,6 \mathrm{~mL} / \mathrm{L}$ air

$\mathrm{P} 2=$ Dosis $0,9 \mathrm{~mL} / \mathrm{L}$ air

$\mathrm{P} 3=$ Dosis $1,2 \mathrm{~mL} / \mathrm{L}$ air

$\mathrm{P} 4=$ Dosis $1,5 \mathrm{~mL} / \mathrm{L}$ air

\subsection{Prosedur Penelitian}

\subsubsection{Persiapan Wadah dan Ikan Uji}

Wadah yang digunakan pada penelitian ini adalah bak fiber dengan kapasitas $100 \mathrm{~L}$. Volume air yang digunakan sebagai media pemeliharaan sebanyak $60 \mathrm{~L}$ air. Sebelum digunakan bak dicuci bersih dan dikeringkan untuk menghindari adanya bibit penyakit. Kemudian diisi dengan air selanjutnya air diberi aerasi.

Pemberian sumber karbon dilakukan dengan rasio $\mathrm{C} / \mathrm{N}$ yaitu 20:1, menurut Avnimelech (2009) bahwa bioflok akan terbentuk jika rasio $\mathrm{C}: \mathrm{N}$ dalam kolam lebih dari 15. Setiap bakteri memerlukan 20 unit karbon untuk setiap 1 unit nitrogen yang diasimilasi $(\mathrm{C} / \mathrm{N}=20: 1)$.

Sumber karbon yang berasal molase (37\% C) diberikan sebanyak $48 \mathrm{~g}$ (Putra et al., 2020). Kemudian campuran tersebut dimasukkan dalam wadah pemeliharaan (ember plastik). Terjadinya pembentukan flok ditandai dengan berubahnya warna air menjadi keruh kecoklatan. Selanjutnya benih belut siap ditebar dan dipelihara di dalam media pemeliharaan. Penambahan molase dilakukan setiap 7 hari

Bahan yang digunakan dalam penelitian ini adalah Belut dengan ukuran 10-15 cm, Boster Sel Multi dengan komposisi tiap $1 \mathrm{ml}$ Sel Multi mengandung microba aktif yaitu Bacillus sp, Nitrosomonas sp, Nitrobacter $s p$ sebagai sumber probiotik, Molase sebagai sumber karbon, lumpur sebagai bahan untuk adaptasi awal belut. Pakan yang digunakan adalah cacing tanah.

\subsubsection{Pemeliharaan Belut}

Sebelum dilakukan penebaran benih belut, terlebih dahulu benih diaklimatisasi untuk menyesuaikan suhu tubuh belut dengan lingkungan yang baru. Aklimatisasi dilakukan dengan cara merendam plastik yang berisi belut selama 15 menit, setelah 15 menit plastik dibuka agar belut keluar dari plastik dengan sendirinya. Setelah dilakukan aklimatisasi untuk belut yang akan digunakan sebagai hewan uji dilakukan seleksi dengan memilih belut yg aktif, tidak cacat, serta tidak terdapat jamur pada tubuh belut.

Tingkat kelangsungan hidup belut tergantung pada padat tebar, padat tebar yang berlebih dapat membuat belut stress, terjadi persaingan dalam memperoleh pakan dan ruang gerak maupun pemanfaatan oksigen terlarut yang mengakibatkan luka stres atau terkena racun. Belut juga memiliki sifat kanibalisme. Padat tebar yang optimum untuk belut pada media budidaya air jernih yaitu 10 ekor untuk setiap $600 \mathrm{~cm}^{2}$ (Perdana, 2013).

Pakan yang diberikan pada belut sawah yaitu cacing tanah. Pakan diberikan 1 kali sehari dengan dosis $15 \%$ dari berat biomassa belut sawah, dan waktu pemberian pakan dilakukan pada sore hari pukul 18.00 WIB. Pengamatan pertumbuhan panjang rata-rata, bobot ikan rata-rata, jumlah ikan yang mati selama penelitian setiap 10 hari sekali yakni dengan mengambil sampel ikan uji sebanyak $30 \%$ dari total populasi ikan pada wadah yaitu 5 ekor (Wulandari, 2006).

\subsection{Parameter yang Diamati}

\subsubsection{Pertumbuhan Bobot Mutlak}

Pertumbuhan bobot mutlak dihitung dengan menggunakan rumus dari Zonneveld et al. (1991) yaitu sebagai berikut:

keterangan:

$$
\mathbf{W m}=\mathbf{W t}-\mathbf{W o}
$$

$\mathrm{Wm}=$ Pertumbuhan bobot mutlak $(\mathrm{g})$

$\mathrm{Wo}=$ Bobot rata-rata pada awal penelitian (g/ekor)

wt = Bobot rata-rata pada akhir penelitian (g/ekor)

\subsubsection{Laju Pertumbuhan Spesifik}

Menurut Zonneveld et al. (1991) laju pertumbuhan spesifik diukur dengan menggunakan rumus:

\section{LPS $=($ LnWt-LnWo $) / t \times 100 \%$}

Keterangan :

$\begin{aligned} \mathrm{LPS} & =\text { Laju pertumbuhan spesifik }(\%) \\ \mathrm{LnWt} & =\begin{array}{l}\text { Bobot rata-rata ikan pada akhir } \\ \text { penelitian }(\mathrm{g})\end{array} \\ \mathrm{LnWo} & =\begin{array}{l}\text { Bobot rata-rata ikan pada awal } \\ \text { penelitian }(\mathrm{g})\end{array} \\ \mathrm{t} & =\text { Lama penelitian (hari) }\end{aligned}$




\subsubsection{Tingkat Kelulushidupan}

Menurut Effendie (2001), tingkat kelulushidupan dapat dihitung dengan rumus sebagai berikut:

$$
S R=\frac{N t}{N o} \times 100 \%
$$

Keterangan:

$$
\begin{aligned}
& \mathrm{SR}= \text { Kelulushidupan }(\%) \\
& \mathrm{Nt}= \text { Jumlah ikan yang hidup pada akhir } \\
& \text { penelitian (ekor) } \\
& \mathrm{No}=\begin{array}{l}
\text { Jumlah ikan yang hidup pada awal } \\
\text { penelitian (ekor) }
\end{array}
\end{aligned}
$$

\subsubsection{Volume Flok}

Mengetahui Volume flok yang terbentuk selama penelitian didalam media budidaya dilakukan pengukuran dengan menggunakan tabung imhoff melalui pengambilan air sebanyak $1000 \mathrm{~mL}$ kemudian diendapkan selama 15 - 30 menit. Flok akan mengendap didasar tabung dan dilakukan penghitungan endapan yang terjadi.

Pengukuran volume flok dilakukan setiap 10 hari dengan mengambil air medium kultur sebanyak 1 liter pada bagian tengah dengan menggunakan wadah yang disebut imhoff-cone. Alat tersebut terbuat dari bahan kaca atau plastik transparan berbentuk kerucut dan dilengakapi dengan skala. Selanjutnya, air tersebut diendapkan selama 30 menit, volume flok dapat dibaca pada skala imhoff-cone (Darmawan, 2017).

\subsubsection{Kualitas Air}

Pengukuran kualitas air berupa suhu, $\mathrm{pH}$, DO, dan amoniak. Pengukuran suhu menggunakan thermometer, DO menggunakan DO meter, pengukuran $\mathrm{pH}$ menggunakan $\mathrm{pH}$ meter dan TAN menggunakan spektrofotometer.

\subsection{Analisis Data}

Data yang diperoleh dari parameter yang diukur meliputi volume flok, pertumbuhan bobot mutlak, laju pertumbuhan spesifik, kelulushidupan belut dan kualitas air akan disajikan ke dalam bentuk tabel, grafik dan dilakukan uji normalitas homogenitas untuk selanjutnya data dianalisis secara statistik menggunakan software SPSS versi 23.

\section{Hasil dan Pembahasan}

\subsection{Laju Pertumbuhan Belut}

Hasil pengamatan pertumbuhan bobot mutlak belut pada semua perlakuan disajikan pada Tabel 1.

Tabel 1. Pertumbuhan Bobot Mutlak dan Laju Pertumbuhan Spesifik Belut (M. albus) dengan Pemberian Dosis Probiotik

\begin{tabular}{cccc}
\hline $\begin{array}{c}\text { Dosis Probiotik } \\
(\mathbf{m L} / \mathbf{L})\end{array}$ & \multicolumn{3}{c}{ Parameter yang diamati } \\
\cline { 2 - 4 } & Bobot Mutlak (g) & Laju Pertumbuhan Spesifik (\%) & Panjang mutlak (cm) \\
\hline 0 & $3,58 \pm 0,28^{\mathrm{a}}$ & $1,21 \pm 0,08^{\mathrm{a}}$ & $2,87 \pm 0,58^{\mathrm{a}}$ \\
0,6 & $6,63 \pm 0,62^{\mathrm{b}}$ & $1,90 \pm 0,16^{\mathrm{b}}$ & $4,73 \pm 0,61^{\mathrm{b}}$ \\
0,9 & $18,91 \pm 0,17^{\mathrm{e}}$ & $3,59 \pm 0,15^{\mathrm{e}}$ & $15,53 \pm 0,50^{\mathrm{e}}$ \\
1,2 & $15,83 \pm 0,29^{\mathrm{d}}$ & $3,26 \pm 0,09^{\mathrm{d}}$ & $11,33 \pm 0,42^{\mathrm{d}}$ \\
1,5 & $11,93 \pm 1,77^{\mathrm{c}}$ & $2,75 \pm 0,24^{\mathrm{c}}$ & $7,67 \pm 1,47^{\mathrm{c}}$ \\
\hline
\end{tabular}

Keterangan: Huruf superscript yang berbeda pada baris yang sama menunjukkan perbedaan nyata $(\mathrm{P}<0,05)$.

Tabel 1 menunjukkan pemberian probiotik sebanyak $0,9 \mathrm{ml} / \mathrm{L}$ air menghasilkan pertumbuhan bobot tertinggi, yaitu $18,91 \mathrm{~g}$, sedangkan terendah tanpa penambahan probiotik sebesar 3,58 g. Sejalan dengan pertumbuhan bobot mutlak, laju pertumbuhan spesifik tertinggi terdapat pada $0,9 \mathrm{~mL} / \mathrm{L}$ air sebesar 3,59\%, dan terendah tanpa pemberian probiotik sebesar $1,21 \%$. Hal ini menunjukkan bahwa pemberian probiotik pada media pemeliharaan mampu meningkatkan pertumbuhan belut.

Hasil analisis variansi (ANAVA) menunjukkan bahwa pemberian probiotik pada media pemeliharaan dengan dosis berbeda memberikan pengaruh antar perlakuannya terhadap pertumbuhan bobot mutlak dan laju pertumbuhan spesifik belut $(p<0,05)$. Uji lanjut Student Newman Keuls (SNK) menunjukkan P2 $(0,9 \mathrm{~mL} / \mathrm{L}$ air $)$ berbeda nyata dengan setiap perlakuan (P0, P1, P3, dan P4).

Pertumbuhan panjang belut yang diberikan penambahan probiotik pada media pemeliharaan berkisar antara 4,73-15,53 cm, sedangkan pada perlakuan Kontrol (P0) sebesar 2,87 $\mathrm{cm}$ hal ini menunjukkan bahwa penambahan probiotik pada media 
pemeliharaan mampu meningkatkan laju pertumbuhan panjang belut. Selanjutnya pertumbuhan panjang mutlak belut yang diberikan penambahan probiotik pada media pemeliharaan memberikan pengaruh antar perlakuan $(p<0,05)$. Hasil analisis variansi (ANAVA) menunjukkan perbedaan nyata antar perlakuan.

Pemberian probiotik pada media pemeliharaan belut memberikan peningkatan terhadap pertumbuhan belut berkisar antara 6,63-18,91 g, jika dibandingkan dengan media pemeliharaan belut yang tidak diberikan probiotik hanya 3,58 g. Hal ini menunjukkan penambahan probiotik memberikan pertumbuhan yang lebih tinggi karena adanya bakteri probiotik yang mampu memperbaiki kualitas air media pemeliharaan sehingga kualitas air terjaga dengan baik. Menurut Suprapto dan Samtamsir (2013) menyatakan bahwa bakteri probiotik juga mampu mengurai bahan organik dalam air yang berasal dari sisa pakan dan feses ikan serta mampu menghilangkan/memanfaatkan senyawa beracun seperti amonia, nitrit, dan nitrat.

Menurut Nayak (2010) probiotik digunakan untuk peningkatan produksi akuakultur, meningkatkan resistensi terhadap penyakit dan membantu dalam peningkatan pertumbuhan. Pertumbuhan menjadi baik karena kondisi lingkungan media pemeliharaan baik, hal ini dikarenakan mikroba dari probiotik dapat membantu memperbaiki kondisi perairan (Khotimah et al., 2016).

Penambahan dosis probiotik pada media pemeliharaan tidak hanya berpengaruh untuk memperbaiki kualitas air, melainkan juga untuk meningkatkan pertumbuhan ikan. Bakteri probiotik secara tidak langsung berinteraksi dengan phytoplankton yang merupakan makanan zooplankton, hal ini menyebabkan perairan tersebut menjadi subur (Hartini et al., 2013).

Rendahnya pertumbuhan pada perlakuan kontrol disebabkan tidak adanya penambahan probiotik sehingga tidak ada bakteri yang dapat mengoksidasi bahan organik, dengan demikian akan terjadi peningkatan bahan organik pada media pemeliharaan dan akan menjadi racun bagi ikan. Menurut Taufik et al. (2005) bahan organik ini mampu memicu timbulnya penyakit dan kurangnya nafsu makan dan berakibat pada rendahnya pertumbuhan benih. Beauty et al. (2012) menyatakan bahwa bakteri probiotik akan menguraikan bahan-bahan organik yang tidak berguna dan beracun serta menurunkan kadar total amoniak yang ada di perairan.

Pemberian probiotik pada media budidaya belut memberikan laju pertumbuhan lebih tinggi (1,21-3,59\%) dibandingkan sistem budidaya dengan pergantian air, yang menghasilkan laju pertumbuhan berkisar antara 0,027-0,070\% (Yusriadi et al., 2017). Hal ini diduga sisa pakan yang diberikan serta feses yang mengendap dapat didegradasi oleh bakteri probiotik. Sesuai pendapat Fuller dalam Khotimah et al. (2016) bahwa probiotik dalam budidaya perikanan berperan antara lain untuk mengatur kondisi mikrobiologi dalam air atau sedimen guna memperbaiki kualitas air media pemeliharaan ikan sehingga dapat meningkatkan kelangsung hidup dan pertumbuhan ikan. Probiotik sendiri adalah makanan tambahan suplemen berupa sel-sel mikroba hidup yang memiliki pengaruh menguntungkan bagi hewan inang yang mengkonsumsinya melalui penyeimbangan flora mikroba.

\subsection{Tingkat Kelulushidupan Belut}

Tingkat kelulushidupan belut selama pemeliharaan berkisar antara 48,89-75,55\%. Kelulushidupan tertinggi pada P2 $(0,9 \mathrm{~mL} / \mathrm{L}$ air) yaitu sebesar $75,55 \%$, sedangkan terendah pada P0 (tanpa penambahan probiotik) sebesar $48.89 \%$. Kelulushidupan belut pada media budidaya dengan pemberian probiotik berkisar antara 55,55-75,55\%, lebih tinggi dibandingkan P0 (tanpa pemberian probiotik) sebesar $48,89 \%$. Hal ini diduga disebabkan P0 terjadi penumpukkan sisa pakan dan feses, sehingga mempengaruhi kualitas media budidaya belut. Sedangkan pada perlakuan dengan penambahan probiotik, sisa pakan dan feses dapat didegradasi oleh bakteri probiotik. Selain itu, Menurut Perez-Sanchez et al. (2014) probiotik meningkatkan stimulasi kekebalan tubuh ikan untuk melindungi terhadap infeksi bakteri patogen.

Bakteri probiotik yang diberikan pada media budidaya belut mampu memberikan tingkat kelulushidupan dengan baik, jika dosis yang diberikan sesuai kebutuhan belut. Pitrianingsih dalam Khotimah et al. (2016) menyatakan bahwa bakteri yang diberikan 
pada media pemeliharaan memberikan pengaruh baik terhadap kelangsungan hidup karena bakteri yang ada mampu mendegredasikan sisa pakan dan feses yang

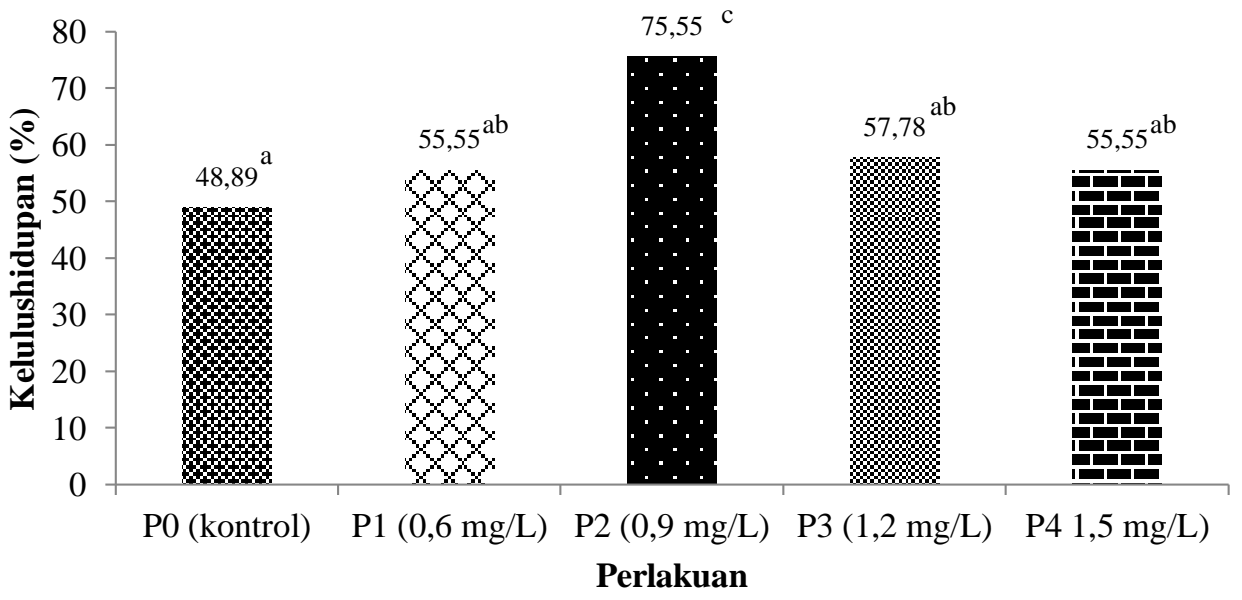

Gambar 1. Tingkat Kelulushidupan Belut (M.albus)

Hasil analisis variansi (ANAVA) menunjukkan bahwa pemberian probiotik pada media budidaya belut memberikan pengaruh antar perlakuan terhadap tingkat keluluhidupan belut $(p<0,05)$. Uji lanjut Student Newman Keuls (SNK) menunjukkan bahwa Perlakuan P2 berbeda nyata dengan P0, namun tidak berbeda nyata dengan $\mathrm{P} 1, \mathrm{P} 3$, dan P4. menjadi pakan alami dalam perairan. Tingkat kelulushidupan belut lebih jelas dapat dilihat pada Gambar 1.

Perlakuan

\subsection{Volume Flok}

Volume flok pada pemeliharaan belut selama penelitian menunjukkan bahwa terjadi peningkatan volume flok pada tiap perlakuannya. Peningkatan volume flok tertinggi pada hari ke 40, yaitu berkisar antara 4,83-11,17 mL/L. Menurut Satish dalam Abrar et al. (2019), kepadatan flok yang diperoleh selama penelitian ini tergolong tinggi $(<10 \mathrm{~mL} / \mathrm{L})$. Lebih Jelas dapat dilihat pada Tabel 2.

Tabel 2. Rata-rata Volume Flok Belut (M. albus) dengan Pemberian Dosis Probiotik

\begin{tabular}{cccccc}
\hline $\begin{array}{c}\text { Dosis Probiotik } \\
(\mathbf{m L} / \mathbf{L})\end{array}$ & $\mathbf{0}$ & $\mathbf{1}$ & $\mathbf{2 0}$ & $\mathbf{3 0}$ & $\mathbf{4 0}$ \\
\cline { 2 - 6 } & - & 1,00 & 4,77 & 2,00 & 4,83 \\
0,6 & - & 1,17 & 4,83 & 4,50 & 11,17 \\
0,9 & - & 1,37 & 5,00 & 6,00 & 7,67 \\
1,2 & - & 1,43 & 3,67 & 6,83 & 10,33 \\
1,5 & - & 1,57 & 3,33 & 8,17 & 10,50 \\
\hline
\end{tabular}

Jumlah flok pada perlakuan P2 (7,67 $\mathrm{mL} / \mathrm{L})$ memiliki nilai terendah dibandingkan perlakuan penambahan probiotik lainnya. Hal ini diduga disebabkan oleh flok yang terdapat dalam media pemeliharaan dapat dimanfaatkan bagi pertumbuhan ikan. Menurut Husein et al. (2014); Abrar et al. (2019), keberadaan flok dalam media pemeliharaan mengindikasikan bahwa inokulan bakteri yang bekerja membentuk flok, sehingga flok dapat dimanfaatkan oleh ikan sebagai pakan tambahan.

\subsection{Kualitas Air}

Kualitas air yang diukur selama penelitian adalah suhu, $\mathrm{pH}$, oksigen terlarut, dan ammonia $\left(\mathrm{NH}_{3}\right)$. Suhu merupakan parameter kualitas air yang berperan dalam laju pertumbuhan metabolisme organisme akuatik. Semakin tinggi suhu maka semakin tinggi pula laju metabolisme dan semakin rendahnya suhu maka semakin rendah pula laju metabolisme sehingga berimplikasi terhadap pertumbuhan belut. suhu berkisar antara $25-30^{\circ} \mathrm{C}$. Kondisi suhu ini termasuk cukup baik untuk pertumbuhan belut. Menurut 
Suparta et al. (2018) suhu yang baik untuk pertumbuhan dan kelulushidupan belut berkisar antara $25-29^{\circ} \mathrm{C}$. Belut tumbuh dan hidup dengan baik $25-32^{\circ} \mathrm{C}$ (Kordi, 2013). Hasil pengukuran kualitas air pada masingmasing perlakuan dapat dilihat pada Tabel 3.

Tabel 3. Pengukuran Kualitas Air Belut Sawah (M. albus) pada Setiap Perlakuan

\begin{tabular}{ccccc}
\hline \multirow{2}{*}{ Dosis Probiotik (mL/L) } & \multicolumn{4}{c}{ Parameter kualitas air } \\
\cline { 2 - 5 } & Suhu $\left({ }^{\mathbf{0}} \mathbf{C}\right)$ & $\mathbf{p H}$ & $\mathbf{D O}(\mathbf{m l} / \mathbf{L})$ & $\left.\mathbf{N H}_{\mathbf{3}} \mathbf{( m g} / \mathbf{L}\right)$ \\
\hline 0 & $26-28$ & $5-6$ & $6,1-7,4$ & $0,00003-0,0005$ \\
0,6 & $25-30$ & $5-6$ & $6,2-7,3$ & $0,00001-0,0003$ \\
0,9 & $26-30$ & $5-7$ & $6,0-7,2$ & $0,00003-0,0001$ \\
1,2 & $25-28$ & $5-7$ & $6,1-7,3$ & $0,00001-0,0001$ \\
1,5 & $26-29$ & $5-7$ & $6,0-7,0$ & $0,00001-0,0003$ \\
\hline
\end{tabular}

pH merupakan parameter kualitas air yang menggambarkan asam maupun basa suatu perairan. $\mathrm{pH}$ juga merupakan salah satu parameter dalam mengidentifikasi pencemaran dalam suatu perairan (Kusnawan et al., 2018). Seperti halnya suhu, pH juga merupakan parameter yang mendukung pertumbuhan dan kelangsungan hidup belut sawah. Berdasarkan hasil pengukuran $\mathrm{pH}$ air selama penelitian berkisar antara 5-7. Nilai ini menunjukkan tergolong baik dan masih dalam batas toleransi untuk budidaya belut. Menurut Saparianto (2010), nilai $\mathrm{pH}$ yang optimal untuk usaha budidaya belut yaitu 5-7. Kordi (2013) menyatakan bahwa nilai $\mathrm{pH}$ di bawah 4 atau di atas 11 menyebabkan kematian pada ikan.

Konsentrasi oksigen terlarut yang diperoleh selama penelitian berkisar antara 6,0-7,4 $\mathrm{mL} / \mathrm{L}$, konsentrasi tersebut masih dalam batas toleransi untuk pemeliharaan belut. Menurut Nhan et al. (2019) kisaran DO yang dapat ditoleransi belut yaitu sebesar 4,5$7,5 \mathrm{~mL} / \mathrm{L}$. Hal ini dikarenakan belut memiliki alat pernapasan tambahan berupa kulit tipis berlendir yang terdapat di rongga mulutnya. Organ ini berfungsi untuk menyerap oksigen langsung dari udara, sementara insangnya digunakan untuk menghirup oksigen di dalam air (Muktiani, 2011).

Konsentrasi amoniak selama penelitian berkisar antara 0,00001-0,0005 $\mathrm{mg} / \mathrm{L}$, konsentrasi tersebut dalam kisaran yang baik untuk kehidupan belut. Konsentrasi amoniak yang dapat ditoleransi oleh belut yaitu $<0,02$ ppm (Firman et al., 2018; Suparta et al., 2018), <0,03 mg/L (Yusriadi et al., 2017). Konsentrasi amoniak pada media pemeliharaan tanpa penambahan probiotik (P0) disebabkan karena penumpukan feses dan sisa pakan pada media pemeliharaan, hal ini terjadi karena tidak adanya bakteri probiotik yang mampu mengurai sisa feses dan sisa pakan. Menurut Khotimah et al. (2017), pemberian probiotik pada media pemeliharaan sangat membantu dalam memperbaiki kualitas perairan karena bakteri yang diberikan mampu mendegradasi sisa pakan dan feses benih ikan.

\section{Kesimpulan dan Saran}

Berdasarkan hasil penelitian, maka dapat disimpulkan bahwa pemberian probiotik pada media pemeliharaan belut memberikan pengaruh terhadap pertumbuhan dan kelulushidupan belut. Dosis $0,9 \mathrm{mg} / \mathrm{L}$ memberikan hasil terbaik terhadap pertumbuhan bobot multak, laju pertumbuhan spesifik, panjang mutlak, kelulushidupan masing masing sebesar 18,91 g, 3,59\%, 15,53 $\mathrm{cm}$, dan $75,55 \%$.

Adapun penelitian lanjutan yang dapat dilakukan tentang selter yang berbeda dalam pemeliharaan belut.

\section{Daftar Pustaka}

Abrar, W.A., N.A. Pamukas, dan I. Putra. (2019). The Effect of Probiotic Addition in Feed towards Growth Performance and Survival Rate of Tambaqui (Colossoma macropomum) using Bioflocs System. Jurnal Perikanan dan Kelautan, 24(1): 32-40

Astawan, M. (2008). Sehat dengan Hidangan Hewani. Penebar Swadaya. Jakarta. 1617.

Avnimelech, Y. (2009). Biofloc Technology: A Practical Guide Book. World Aquaculture Society: Louisiana, USA. $120 \mathrm{pp}$.

Beauty, G., Y. Ayi, dan G. Roffi. (2012). Pengaruh Dosis Mikroorganisme 
Probiotik pada Media Pemeliharaan terhadap Kelangsungan Hidup dan Pertumbuhan Benih Mas Koki (Carassius auratus) dengan Padat Penebaran Berbeda. Jurnal Perikanan dan Kelautan, 3(3):1-6.

Darmawan. 2017. Pemeliharaan Ikan Patin Siam (Pangasius hypopthalmus) dengan Teknologi Bioflok pada Media Air Rawa Gambut. Skripsi. Fakultas Perikanan dan Kelautan. Universitas Riau.

Firman, M., Idris, dan O. Astuti. (2018). Pengaruh Shelter yang Berbeda terhadap Pertumbuhan dan Kelangsungan Hidup Belut Sawah (Monopterus albus) yang dipelihara pada Media Tanpa Lumpur. Media Akuatika, 3(3): 702-712.

Hartini, S., D.S. Ade., dan H.T. Ferdinand. (2013). Kualitas Air, Kelangsungan Hidup dan Pertumbuhan Benih Ikan Gabus (Channa striata) yang Dipelihara dalam Media dengan Penambahan Probiotik. Jurnal Akuakultur Rawa Indonesia, 1(2): 192202.

Husein, N., P. Berta, dan Supono. (2014). Perbandingan Karbon terhadap Produksi Budidaya Intensif Nila (Oreochromis niloticus). Journal of Aquaculture Management and Technology, 1(1): 161-179.

Khotimah, K., E.D. Harmilia, dan R. Sari. (2016). Pemberian Probiotik pada Media Pemeliharaan Benih Ikan Patin (Pangasius hypophthalmus) dalam Akuarium. Jurnal Akuakultur Rawa Indonesia, 4(2): 152-158.

Khotimah, K., Helmizuryani, dan J. Saputra. (2017). Peran Probiotik pada Pakan dan Media Pemeliharaan terhadap Peningkatan Pertumbuhan dan Kelangsungan Hidup Benih Ikan Patin (Pangasius hypophthalmus). Fisheries, 6(2): 12-16

Kordi, M.G. (2013). Budidaya Belut di Pekarangan, Lahan Kritis dan Minim Air. Pustaka Baru. Yogyakarta.

Kusnawan, I., W.H. Muskita, dan M. Idris. (2018). Pengaruh Penambahan Tepung Cacing pada Pakan Formula terhadap Pertumbuhan dan Kelangsungan Hidup Belut Sawah (Monopterus albus) yang
Dipelihara di Media Tanpa Lumpur. Media Akuatika, 3(3): 713-722

Ma'in, S. Anggoro, dan S.B. Sasongko. (2013). Kajian Dampak Lingkungan Penerapan Teknologi Bioflok pada Kegiatan Budidaya Udang Vaname dengan Metode Life Cycle Assessment. Jurnal Ilmu Lingkungan, 11(2): 110119.

Mashuri., Sumarjan, dan Z. Abidin. (2012). Pengaruh Jenis Pakan yang Berbeda Terhadap Pertumbuhan Belut Sawah (Monopterus albus Zuieuw). Jurnal Perikanan Unram, 1(1):1-7.

Matondang, P.A.S., U.M. Tang, dan I. Putra. (2019). Growth Performance of Asian Redtail Catfish (Hemibagrus nemurus) with Different Stocking Density on Boster System. Jurnal Online Mahasiswa Fakultas Perikanan dan Ilmu Kelautan, 6(1): 1-14

Muktiani. (2011). Menggeluti Bisnis Belut (Seri Perikanan Modern). Pustaka Baru. Yogyakarta.

Nayak, S.K. (2010). Probiotics and Immunity: A Fish Perspective. Review. Fish and Shellfish Immunologi, 29:2-14.

Nhan, H.T., N.T. Tai., P.T. Liem., V.N. Ut., dan H. Ako. (2019). Effects of Different Stoking Densities on Growth Performance of Asian Swamp Eel Monopterus albus, Water Quality and Plant Growth of Watercress Nasturtium officinale in an Aquaponic Resirculating System. Aquaculture, 503: 96-104

Nurrahmad, A. (2020). Pertumbuhan dan Kelulushidupan Belut Sawah (Monopterus albus) yang dipelihara dengan Padat Tebar Berbeda pada Sistem Bioflok. Skripsi. Fakultas Perikanan dan Kelautan. Universitas Riau.

Perdana, B.P. (2013). Kinerja Produksi Belut Monopterus albus pada Media Budidaya yang Berbeda. Skripsi. Bogor. Fakultas Perikanan dan Kelautan. Institut Pertanian Bogor.

Perez-Sanchez, T., I. Ruiz-Zarzuela, I.D. Blas, dan J.L. Balcazar. (2014). Probiotics in aquaculture: A current assessment. Reviews in Aquaculture, 6:133-146. 
Putra, I., I. Effendi, I. Lukistyowati, U.M. Tang, M. Fauzi, dan I. Suharman. (2020). Effect of Different Biofloc Starters on Ammonia, Nitrate, and Nitrite Concentration in the Cultured Tilapia Oreochromis niloticus System. F1000Research 9

Saparianto, C. (2012). Panduan Lengkap Belut. Penebar Swadaya. Jakarta.

Suparta, S., M. Idris., dan A.M. Balubi. (2018). Pengaruh Ketinggian yang Berbeda terhadap Pertumbuhan dan Kelangsungan Hidup Belut Sawah (Monopterus albus) yang dipelihara pada Media Tanpa Lumpur. Media Akuatika, 3(4): 787-794.

Suprapto, N.S., dan L.S. Samtamsir. (2013). Rahasia Sukses Teknologi Budidaya Lele Hemat Lahan, Hemat Air, Hemat Pakan, Lebih Bersih, dan Non-residu Serta Kualitas Daging Lebih Enak. Agromedia 165. Depok-Jawa Barat.
Taufik, I., H. Supriadi, I. Muthalib, P. Yulianti, dan S. Subandiyah, (2005). Studi Pengaruh Suhu Air terhadap Aktifitas Bakteri Bioremediasi pada Pemeliharaan Benih Ikan Patin Siam (Pangasius hypopthalmus). Jurnal Penelitian Perikanan Indonesia.

Wulandari, A. R. (2006). Peran salinitas terhadap kelangsungan hidup dan Pertumbuhan Benih Ikan Bawal Air Tawar (Colossoma macropomum). Skripsi. Fakultas Perikanan dan Ilmu Kelautan. Institut Pertanian Bogor.

Yusriadi, A., M. Idris, dan R.S. Patadjai. (2017). Pengaruh Pergantian Air terhadap Pertumbuhan dan Kelangsungan Hidup Belut Sawah (Monopterus albus) yan dipelihara pada Media Tanpa Lumpur. Media Akuatika, 2(4): 519-525.

Zonneveld, N., E.A. Huisman, dan J.H. Boon. (1991). Prinsip-prinsip Budidaya Ikan Diterjemahkan oleh Tirtajaya. Gramedia Pustaka Utama. Jakarta. 318 hlm 